\title{
THE RECEPTION OF THE THEOLOGY OF KARL BARTH IN SCOTLAND ${ }^{1}$
}

\author{
John L. McPake
}

This thesis seeks to challenge the account of the reception of Karl Barth's theology within Scotland as offered by the leading Scottish theologian Thomas Forsyth Torrance (1913-). Equally, and consonant with that intention, it examines the nature of Hugh Ross Mackintosh's (1870-1936) response to Barth's theology (both Mackintosh and Barth having been teachers of Torrance). Torrance has championed Barth within the Englishspeaking world as the theologian par excellence, and presented his own thought as standing in self-conscious fidelity to that of Barth. Therefore, his account of the reception is of crucial significance.

In Chapter 1 ('The Reception of the theology of Karl Barth: Two Perspectives on the Scottish Situation'), I demonstrate that Torrance offers a relatively 'established' understanding of the way in which Barth's theology was received within Scotland. This understanding I term the 'Discontinuity Scenario', given that it posits a discontinuity between Barth's thought and that of Albrecht Ritschl and Wilhelm Herrmann, especially with respect to the nature of God's self-revelation.

Alongside this, I content that, in Scotland, Mackintosh is portrayed as the principal positive recipient of Barth's thought, and that Mackintosh's response to Barth turned upon the rejection of a line of theological thought which had formerly been highly influential upon him, namely that of Ritschl and Herrmann. The cause of this rejection, which parallels Barth's own rejection, is adduced to be Mackintosh's dissatisfaction

${ }^{1}$ John L. McPake, H.R. Mackintosh, T.F. Torrance and the Reception of the Theology of Karl Barth in Scotland-with Particular Reference to the Concept of the Self-Revelation of God (Unpublished Ph.D. dissertation, University of Edinburgh, 1994); supervisor: Dr. Kevin J. Vanhoozer. 
with the understanding of the nature of revelation found in Ritschl and Herrmann. This rejection stands in contrast to the warm reception given by Mackintosh to Barth. Thus, within Torrance's account, the theological core provided by the concept of the self-revelation of God offers the essential clue to discerning the contours of the history of theology. That is, to discerning those theologians (e.g. Athanasius, Calvin, Mackintosh, Barth) who have theologised in fidelity to the truth of God's self-revelation, and those who have not, I grant to the Discontinuity Scenario the status of a 'paradigm'.

In contrast, I offer an alternative 'Continuity Scenario'. A central element in this scenario is the contention that Mackintosh's positive response to Barth turned not on a rejection of Ritschl and Herrmann, but on an appreciation of the fact that Barth and Herrmann stood in a relationship of theological continuity with respect to their understanding of the nature of God's self-revelation (although the form in which that understanding is expressed differs). That is, I suggest that the 'paradigm' is unsatisfactory in the light of the fact that the theological core which lies at the heart of Barth's understanding is intimately related to the theological core which lies at the heart of Herrmann's understanding. (The establishing of the nature, or degree, of this relationship is an integral element within the thesis, and is fully worked out in Chapter 4). The failure to acknowledge this relationship may potentially render Barth a poor guide as to the history of theology. Thus, Torrance, in following Barth, has at the heart of his own position a theological concept whose history he has not properly discerned.

In Chapter 2 ('H.R. Mackintosh and the reception of Barth'), I seek to justify my revisionist reading of Mackintosh, and credit him with one of the first sightings of the significance of Barth. Alongside this, I demonstrate that Mackintosh's relationship to that stream of thought, which we may term Ritschlian, was more extensive and persistent than Torrance's account would have us believe. In particular, I contend that Mackintosh makes a careful distinction between the thought of Ritschl and the later Ritschlians such as Herrmann, such that he may soundly criticise the former while acknowledging the 
significant progress made by Herrmann in articulating an understanding of the nature of God's self-revelation which is in harmony with the New Testament. Equally, I maintain that in commending Herrmann, Mackintosh understands his progress to be in a similar direction to that of Herrmann's former pupil: Karl Barth. The distinction noted above is crucial, and has been overlooked by Torrance. Therefore, I contend that the thought of the later Ritschlians, such as Herrmann, and of Barth are to be understood as mutual influences on the thought of Mackintosh, rather than as mutually exclusive resources for the theological task.

In Chapter 3 ('Barth in Scotland: The Wider Picture, 1924-1939'), I place Mackintosh's reception of Barth in the wider Scottish context and demonstrate that Scottish theology was significantly influenced by Barth's theology in this period, and that the question of the nature of God's revelation was very much to the fore.

Having established the Scottish context within which the reception of Barth took place, I then turn in Chapter 4 ('Ritschl and Herrmann on Revelation and the concept of the self-revelation of God: An indispensable preface to Barth's thought') to an exposition of Ritschl's general position and to an identification of those elements in his teaching which (allied to a Kantian epistemology) provided the framework for Herrmann's concept of the self-revelation of God. I demonstrate that Herrmann radicalises Ritschl's position, and that his teaching can be differentiated from that of Ritschl. I contend that Barth's understanding of God's self-revelation may be understood as a further radicalising of that position, in the direction already taken by Herrmann. However, although I argue strongly for the latter point, I maintain that this should not be taken as signifying an absolute departure from that position. Therefore, Barth's concept of the self-revelation of God can only properly be understood in terms of its relation to Herrmann's concept.

Chapter 5 ('T.F. Torrance on the nature of God's Revelation: With particular reference to Theological Science') offers an exposition of Torrance's thought which demonstrates his considerable dependence on Barth. I note that in his book 
Theological Science (1969) and thereafter, Torrance claims to discern within Barth a theological epistemology paralleling the scientific epistemology of Einstein, et al. This appears to be a self-conscious attempt to advance beyond Barth, albeit one which he claims has received Barth's endorsement. I judge Torrance's position at this point to be illegitimate, from the standpoint of one who self-consciously avows fidelity to Barth's thought. The basis for this judgement lies in the fact that Barth's concept of the self-revelation of God is correlated to an essentially Kantian understanding of the boundaries of the discipline of theology, which would prohibit in principle the development Torrance proposes. This concept, so correlated, indicates that Barth's position can only be understood in terms of its relationship to the thought of Herrmann, and the Ritschlian tradition. Therefore, Torrance's failure to discern the extent to which Barth's concept stands in continuity with that of Herrmann, and his failure to acknowledge that the developments within his own thought place him in discontinuity with Barth, renders his account of Barth's theology incoherent.

In conclusion, I argue in Chapter 6 that we should set aside the Discontinuity Scenario, on the basis that it is an inadequate account of the history of the theology from within a Scottish perspective, and that, generally speaking, it provides an inadequate basis for understanding the concept of the selfrevelation of God within the thought of Karl Barth. 